\title{
The Effects of DBE Goals on Bid Success Rates
}

\author{
Samuel L. Myers, Jr. \\ University of Minnesota \\ Man Xu \\ University of Minnesota
}

Federally mandated aspirational disadvantaged business enterprise (DBE) goals for public procurement are designed to remedy current or ongoing discrimination. Legal concerns suggest that DBE goals might discriminate against non-DBEs by raising the cost of bids and producing lower bid success rates for nonDBEs than what would have occurred had there not been requirements for DBE goals. The authors combine data on DBE certification and contract and procurement bids to test the hypothesis that non$D B E s$ are discriminated against in the presence of DBE goals. Across multiple specifications and estimation methods, we find no compelling evidence that DBE goals discriminate against non-DBEs.

Keywords: Disadvantaged Business Enterprise Goals (DBEs), non-DBEs, Bid Success Rates

\section{BACKGROUND}

Billions of dollars are spent annually by state, local and federal agencies on race-conscious programs designed to increase the share of public dollars awarded to women and minority-owned business enterprises (Myers and Ha, 2018). The public procurement and contracting process by which these expenditures are made, where government agencies require prime contractors that are competing for federal, state and local highway or bridge construction contracts, military contracts, transit system contracts, and billions of dollars in other contracting and procurement activities is designed to meet affirmative action goals for subcontracting to disadvantaged-, women-, and minority-owned businesses. The rationale for these affirmative action efforts is the ongoing disparity between the availability and utilization of disadvantaged businesses often resulting in huge disparities in the size of prime and subcontracts awarded to white male-owned firms as compared to women- and minority-owned business firms. These programs began as a response to the 1968 Kerner Commission Report findings that civil unrest was linked to barriers to business ownership among minorities (Gooden and Myers, 2018). In 1978, the United States Congress enacted Public Law 95-507, which required all federal agencies to set percentage goals for the awarding of contracts to small minority-owned businesses.

This initiative followed the authorization of minority set-asides in the 1977 Public Works Employment Act (PWEA), which stemmed from a floor amendment introduced by Maryland's Seventh District Congressman Parren Mitchell. In City of Richmond v. J. A. Croson Co. (1989), the United States Supreme Court ruled that minority business set-asides in public procurement and contracting generally are suspect and must meet a strict-scrutiny test to be constitutional. Even when there is a factual predicate 
for implementing a race-conscious affirmative action program, there remains the question of whether minority business set-asides are effective in achieving improved performance among the intended beneficiaries. The Clinton administration sought to find a middle ground in its effort to salvage this and other forms of affirmative action (Myers and Chan, 1997). The solution sought in the case of agencies receiving Federal Transit Authority (FTA) funds was to require that goals established to assist disadvantaged business enterprises (DBEs) be narrowly tailored, flexible, and not overly inclusive and minimize the burden placed on other firms. Federal Transit Authority guidelines dictate that DBE goals be set triennially and that they be computed from estimates of the supply of ready, willing and able DBEs in the relevant geographic marketplace. (49 CFR Part 26 -Subpart C)

A perennial complaint about DBE goals programs is that they might discriminate against non-DBEs. The underlying logic is that in the absence of goals, non-DBEs would bid on contracts and offer the lowest possible bid price. The introduction of a goal, according to this logic, requires firms to seek out subcontractors that are more costly and thereby forces the non-DBEs to raise their bid price. The result, putatively, is that the bidder faces lower success rates than would have occurred had there been no DBE goal.

This effect of DBE goals on bid success rates is an empirically testable effect. However, there are two complementary concerns when modeling the impacts of DBE goals on success rates. First, DBE bidders presumably benefit from DBE goals and thus one needs to examine whether any possible gains to DBEs offset any potential losses to non-DBEs. In this sense, the examination focuses on whether any observed discrimination against non-DBEs can be justified by improvements in the success rates of DBEs.

A second concern is that well-situated firms can offer many bids and that "success" should not be measured based on the outcomes of any one bid; rather it should be based on the average across all of a firm's bids. The sheer volume of bids of a highly successful firm might produce low bid success rates. An analogy is that of an economist who submits 100 papers for publication and might receive 75 rejections and 25 acceptances in a span of 10 years. This works out to 2.5 publications per year. An economist with a lower productivity of submitting 10 papers for publication over a span of 10 years but who receives 5 acceptances and thus yields .5 publications per year actually has a success rate of 50 percent vs. 25 percent. The difference, of course, is attributable to the base measurement: rate per paper vs. rate per author.

This paper builds on a growing literature that addresses the question of the efficiency of DBE programs. Using bid data from the Texas Department of Transportation (TxDOT), De Silva et al. (2012) find that contracts with DBE goals have a higher number of bids and that bidding on such contracts does not change the cost structure and bidding behavior. In a later paper, employing evidence on a ten-year DBE training program, De Silva et al. (2019) conclude that the DBE training program generates substantial savings for the state and that program graduates are positioned to bid more aggressively. These papers, then, suggest that there are efficiencies associated with DBE programs. Contrary evidence, however, from California's Proposition 2009 shows a reduction in project costs with the elimination of a state-level DBE participation program in California (Marion, 2009 and 2011). This contrary evidence points to the possibility that DBE goals programs limit opportunities for non-DBEs who putatively face lower project costs than DBEs.

In addition to studies on the efficiency of DBE goals programs, there is an abundance of evidence concerning the utilization of DBEs by way of the subcontracting process. Examining a unique program employed by the Iowa Department of Transportation before 2013, Marion (2017) shows that allowing subcontracting based on DBE utilization history can improve government expenditures and maintain DBE utilization at the same time. Similarly, focusing on the subcontracting DBE utilization requirements at the New Mexico Department of Transportation (NMDOT), Rosa (2018) suggests an insignificant relationship between DBE subcontracting requirements and procurement costs. Subcontracting with DBE requirements at NMDOT significantly increases the awarded dollars to DBE subcontractors, yet only increases procurement costs slightly.

This paper does not address the question of DBE subcontracting. Instead, it focuses on the bid success rates of prime contractors faced with DBE goals requirements. We examine first whether non-DBEs are 
discriminated against in a DBE-goals based public procurement and contracting environment. We also test whether the mechanism for discrimination against non-DBEs is the DBE goals themselves, which presumably increase the cost of bids.

In the remainder of this paper, we review a key piece of litigation from Minnesota concerning a nonDBE that alleged discrimination arising from a DBE program. We then detail a model designed to detect whether DBE goal setting results in discrimination against non-DBEs, taking into account the possibility that non-DBEs include DBEs who benefited from the goals but have graduated. The data and estimation results follow. We conclude with a discussion of the legal and economic implications.

\section{THE GEYER VS. MNDOT CASE}

Geyer Signal, a small family-owned traffic control company sued the Minnesota Department of Transportation (MnDOT) claiming that the Agency's DBE program discriminates against white males.

Geyer Signal, founded and majority owned by Kevin Kissner, a white male, bids annually on thousands of small projects. The plaintiff claimed in the disposition that it lost bids because of the DBE program and that the MnDOT implementation of the program violated the Fifth and Fourteenth Amendments of the US Constitution. The plaintiff also alleged that the defendants intentionally and unlawfully discriminated against the plaintiff in violation of 42 U.S.C. $§ 1981$ and excluded the plaintiffs from participation in, denied the plaintiffs benefits of, and subjected the plaintiffs to discrimination under a program that received federal financial assistance, on the grounds of Kevin Kissner's race (Geyer Signal, Inc. et al v. Minnesota Department of Transportation et al, 2014). The plaintiff also offered a novel theory that the cause of the constitutional violations arose from the application of DBE goals in industries where DBEs were in overabundance. The use of goals in market sectors where there is an overconcentration of potential DBE bidders amounted to prima facie evidence of discriminatory intent by the defendants according to this theory.

The defendants in the case included the Minnesota Department of Transportation and the United States of America, the United States Department of Transportation, and the Federal Highway Administration (Intervenor Defendants). Expert witness reports by Myers (2013) were submitted and the defendants requested summary judgment or dismissal of the case based on the evidence provided by expert witnesses showing that the bid success rates were not lower for the plaintiff than DBEs and that the traffic control and signaling industry in the local market did not show a pattern of overconcentration of DBEs. Judge John R. Tunheim ruled in favor of the defendants writing that

"Because the Court concludes that Plaintiffs have raised no genuine issue of material fact with respect to the constitutionality of the DBE Program facially or as applied, it will grant Defendants' motions in their entirety ... The Court finds that these disputes with MnDOT's conclusion that discrimination exists in public contracting are insufficient to establish that MnDOT's implementation of the DBE Program is not narrowly tailored ... Plaintiffs have not shown that MnDOT's reliance on its overconcentration analysis using NAICs codes was unreasonable or that overconcentration exists in its type of work as defined by MnDOT, it has not established that MnDOT has violated narrow tailoring by failing to identify overconcentration or failing to address it. Accordingly, the Court will grant the State Defendants' motion for summary judgment with respect to this claim." (Geyer Signal, Inc. et al v. Minnesota Department of Transportation et al, 2014).

\section{THE MODEL}

Ideally, one would want to consider three groups of bidders: non-DBEs (denoted by n), DBEs (denoted by d), and DBEs that have graduated (denoted by d'.) By definition, DBEs are economically and socially disadvantaged. Non-DBEs are determined not to be both economically and socially disadvantaged. Graduated DBEs remain socially disadvantaged but are no longer economically 
disadvantaged by certification. Thus, one way to determine the separate effects of economic disadvantage vs. social disadvantage on bid success rates is to compare the impacts of a DBE goal on the bid success rates of graduated vs. other DBEs.

To determine whether there is discrimination against non-DBEs in DBE goals programs, one can compare the bid success rates of non-DBES with the counterfactual bid success rates of non-DBEs when they are treated like DBEs. One can further compare the success rates of non-DBEs with and without DBE goals. The first comparison is a comparison between DBEs and non-DBEs. The second comparison is between non-DBEs without goals and non-DBEs with goals. These two comparisons together form the basis for the claims that the DBE program discriminates against non-DBEs.

Let $\mathrm{P}(\mathrm{b})$ be the probability of bid success, conditioned on $\boldsymbol{x}$, a vector of firm characteristics, such as size, credit rating, tenure, type of ownership, and industry; $\boldsymbol{G}$, an indicator of the DBE goal set on the contract on which the firm bids; and $\boldsymbol{C}$, other characteristics of the contract, such as the size, duration, or type of work; and $\boldsymbol{t}$, the contract bid year.

The probability of bid success can be estimated separately for non-DBEs, DBEs, and graduated DBEs. The test for whether there is discrimination against non-DBEs is a test that the bid success rates for non-DBEs is significantly lower than the bid success rate for non-DBEs when they are treated like identically situated DBEs, or when the equal treatment probability of success for non-DBEs is higher than the actual success rate for non-DBEs.

To test whether any discrimination found against non-DBEs is attributable to race-conscious DBE goals and not due simply to the economic disadvantage of DBEs, one can compare the non-DBE bid success rate with the equal treatment value of the success rate for non-DBEs computed at the treatment of graduated DBEs. Graduated DBEs remain socially disadvantaged, but they are no longer economically disadvantaged in the sense that they are no longer certified as socially and economically disadvantaged.

The probability of bid success for non-DBEs:

$P^{n}(b)=f\left(\beta^{n} x^{n} ; \gamma^{n} G ; \phi^{n} C ; t\right)$

The probability of bid success for DBEs:

$P^{d}(b)=f\left(\beta^{d} x^{d} ; \gamma^{d} G ; \phi^{d} C ; t\right)$

The probability of bid success for graduated DBEs:

$P^{d \prime}(b)=f\left(\beta^{d \prime} x^{d \prime} ; \gamma^{d^{\prime}} G ; \phi^{d \prime} C ; t\right)$

The non-discriminatory probability of bid success for non-DBEs:

$\tilde{P}^{n}(b)=f\left(\beta^{d} x^{n} ; \gamma^{d} G ; \phi^{d} C ; t\right)$

The key test that we wish to conduct is whether $\tilde{P}^{n}(b)=P^{n}(b)$, or whether the non-discriminatory bid success rates for non-DBEs differs from the actual bid-success rates, controlling for firm characteristics, DBE goals, and other characteristics of the contract and year. Note that the nondiscriminatory value of the non-DBE bid success rates can be estimated from the coefficients obtained on the DBE variables or on the graduated DBE variables. When estimated on the graduated DBE variables, the result is one that isolates social disadvantage from economic disadvantage. The tests can be conducted across multiple specifications and estimations.

Typically, there are not enough observations to estimate equations (2) or (3) and thus to obtain the equal treatment or non-discriminatory probability of bid success for non-DBEs in equation (4). An alternative is to estimate equation (5), which is a conventional method of capturing differential treatment of equally qualified non-DBEs and DBES: 
The estimated coefficient $\hat{\delta}$ on the non-DBE variable $(\mathrm{N})$ measures any adverse impact of non-DBE status on bid success rates across all bidders. To test whether non-DBEs face lower bid success rates in the face of DBE goals, we estimate equation 1 and compute $\widehat{\gamma^{n}}$, or the impacts of DBE goals on the bid success rates of non-DBEs.

\section{THE DATA AND DESCRIPTIVE STATISTICS}

New Jersey Transit is the nation's third largest provider of bus, rail and light rail transit and links major points in New Jersey, New York City and Philadelphia. (NJ Transit, 2018). We obtained information on awarded contracts, bidder lists and certified DBE lists for New Jersey Transit Corporation for 2007-2013. This information was merged with D\&B Hoover records to obtain measures of firm-level characteristics. The awarded contracts included both prime contracts and their associated sub-prime contracts, which contain detailed award information. One can merge information on awarded contracts with bidder lists by contract number to identify the bid winner.

There are two conceptual measures of bid success: at the bid level or at the bidder level. The bidders list is at the bid level, and for each contract there is one winning bid. One can compute the bid success rate for DBEs vs. non-DBEs using this bid level data. A firm, however, can conceivably bid on more than one contract across a time span. Thus, a firm can appear more than once in the bidders list. Thus, we also compute the bid success rates at the bidder or firm level, where the unit of observation is the firm.

To differentiate between DBE and non-DBE bidders, we matched the DBE list with the contracts and the bidder list and recorded the gender, race and ethnicity, and DBE certification status of each bidder. We also gathered additional information on industrial classification (North American Industry Classification System codes (NAICS)), firm size, annual revenue, employment, tenure, and credit rating from the D\&B Hoover database for each firm. 


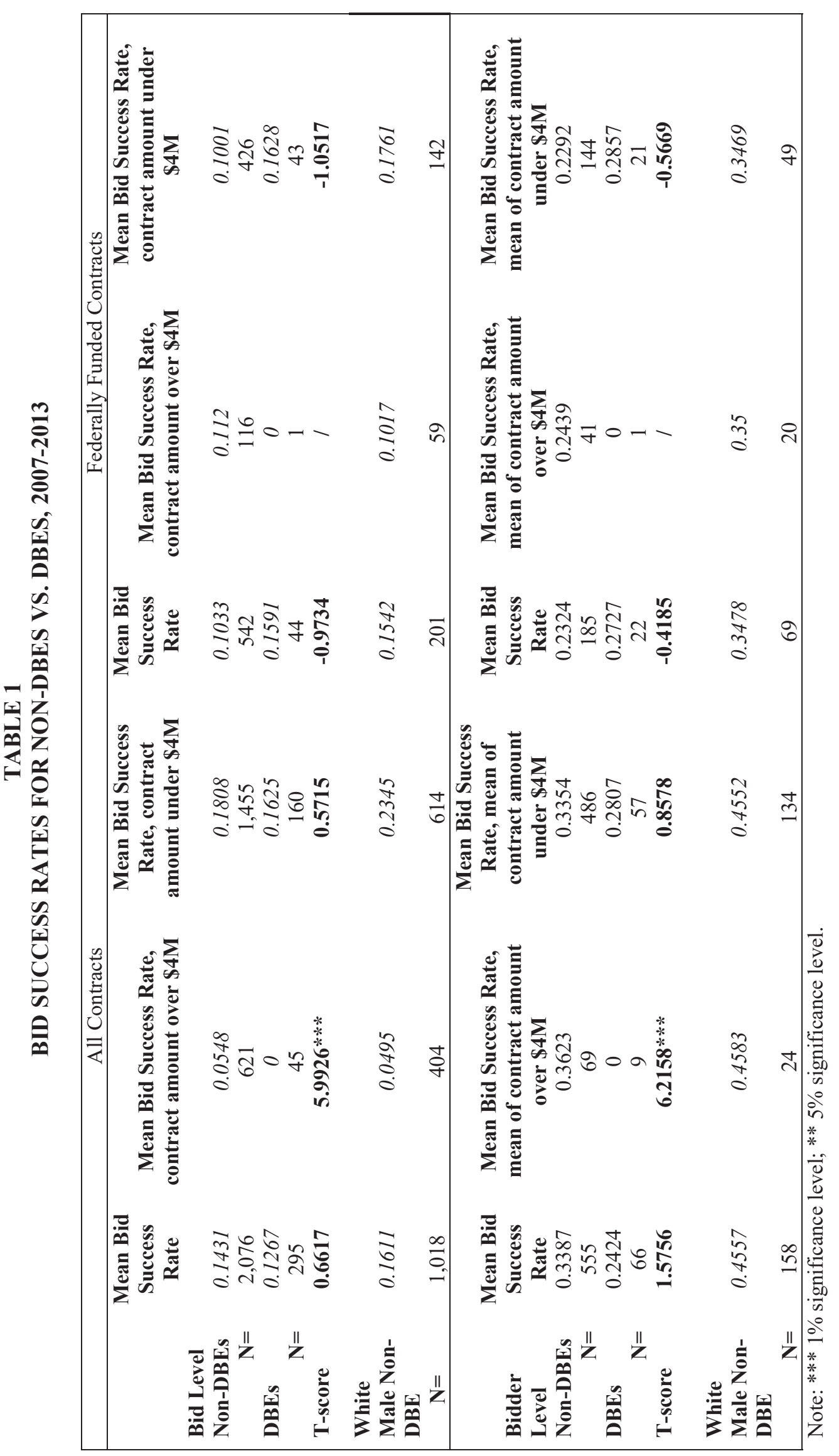

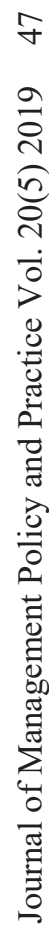


Table 1 reports the results of testing for differences in the bid success rates between DBEs and nonDBEs at the bidder level and the bid level. We also report the results of computing the differences between DBEs and white male non-DBEs. White male non-DBEs are a significant subset of non-DBEs, which can include women or minorities who are not economically disadvantaged. Table 1 shows that there are no statistically significant differences in the bid success rates for DBEs and non-DBEs for all contracts, whether measured at the bid level or the bidder level, and non-DBEs have higher bid success rates for all contracts. However, for large contracts, non-DBEs are far more likely to be successful than DBEs. Not a single DBE won a contract over $\$ 4$ million. For federally funded smaller contracts under $\$ 4$ million, there is a slightly higher probability of bid success among DBEs vs. non-DBEs. White male nonDBEs have the highest bidding success rates across different contract amounts at the bidder level.

Similarly, table 2 reports the bid success rates for non-DBEs with and without goals only for federally funded contracts. Based on the availability of DBEs and potential DBEs to perform the types of work that NJ Transit intends to contract, NJ Transit assigns a specific DBE goal to an upcoming contract. The Office of Civil Rights' Office of Business Development (OBD) reviews all prime contractor documentation to ensure the DBE goal is complete, accurate and adequate to establish. Then, through the lifetime of the contract, OBD tracks the DBE goal to determine if it is attained and/or if a good faith effort was made to attain the goal (NJ Transit, 2019). Table 2 reveals that when measured at the bid level, nonDBEs bidding on contracts with DBE goals have lower success rates than non-DBEs bidding on contracts without goals. The difference is not statistically significant for federal contracts. Table 3 replicates the results in Table 2 but for white male non-DBEs. White male non-DBEs bidding on contracts without goals have higher success rates than white male non-DBEs with goals, but the difference is not statistically significant.

TABLE 2 BID SUCCESS RATES FOR NON-DBES WITH VS. WITHOUT GOALS, FEDERALLY
FUNDED CONTRACTS, 2007-2013

\begin{tabular}{|lcccc|}
\hline & & $\begin{array}{c}\text { Mean Bid Success } \\
\text { Rate }\end{array}$ & $\begin{array}{c}\text { Mean Bid Success Rate, } \\
\text { over } \mathbf{\$ 4 M}\end{array}$ & $\begin{array}{c}\text { Mean Bid Success Rate, } \\
\text { under } \mathbf{\$ 4 M}\end{array}$ \\
\hline Without goal & & 0.1429 & $/$ & 0.1429 \\
With goal & $\mathbf{n}=$ & 98 & 0 & 98 \\
& & 0.0946 & 0.1121 & 0.0884 \\
T-score & $\mathbf{n}=$ & 444 & 116 & 328 \\
& & 1.2650 & $/$ & 1.4016 \\
\hline
\end{tabular}

TABLE 3

BID SUCCESS RATES FOR WHITE MALE NON-DBES WITH VS. WITHOUT GOALS, FEDERALLY FUNDED CONTRACTS, 2007-2013

\begin{tabular}{|lcccc|}
\hline & & $\begin{array}{c}\text { Mean Bid Success } \\
\text { Rate }\end{array}$ & $\begin{array}{c}\text { Mean Bid Success Rate, } \\
\text { over \$4M }\end{array}$ & $\begin{array}{c}\text { Mean Bid Success Rate, } \\
\text { under \$4M }\end{array}$ \\
\hline Without goal & & 0.2187 & $/$ & 0.2187 \\
With goal & $\mathbf{n}=$ & 32 & 0 & 32 \\
& & 0.1420 & 0.1017 & 0.1636 \\
T-score & $\mathbf{n}=$ & 169 & 59 & 110 \\
\hline
\end{tabular}

In New Jersey, only federal contracts have DBE goals. There are no race-conscious goals on state contracts. Nevertheless, New Jersey does have race-neutral goals in the form of small business enterprise goals. To test whether there is a disparity in bid success rates for non-DBEs purely as a result of goals 
(and not necessarily as a result of race-conscious goals), we compute the bid success rates for state contracts with and without Small Business Enterprise (SBE) goals. Table 4 reports the results. There is virtually no difference between the success rates of non-DBEs between contracts with goals or contracts without goals. This finding is true whether one measures the bid success rate at the bid level or at the bidder level.

As a purely descriptive exercise, we find no compelling evidence that DBE goals result in lower success rates for non-DBEs. This descriptive evidence, however, ignores the many differences between DBEs and non-DBEs that are unaccounted for in tests for differences in mean success rates. It is useful, therefore, to explore whether, controlling for firm characteristics and contract characteristics, we can reject the hypothesis that non-DBEs are discriminated against and whether there are differential impacts on non-DBEs arising from DBE goals.

TABLE 4

BID SUCCESS RATES FOR NON-DBES WITH VS. WITHOUT SBE GOALS, STATE FUNDED CONTRACTS, 2007-2013

\begin{tabular}{|c|c|c|}
\hline & $\begin{array}{l}\text { Mean Bid Success } \\
\text { Rate, Bid-level }\end{array}$ & $\begin{array}{c}\text { Mean Bid Success Rate, } \\
\text { Bidder-level }\end{array}$ \\
\hline Without SBE goal & 0.2778 & 0.3529 \\
\hline $\mathbf{n}=$ & 108 & 51 \\
\hline With SBE goal & 0.2175 & 0.3437 \\
\hline $\mathbf{n}=$ & 855 & 352 \\
\hline T-score & 1.4140 & 0.4488 \\
\hline
\end{tabular}

\section{TABLE 5 VARIABLE DEFINITIONS}

\begin{tabular}{|ll|}
\hline \multicolumn{1}{|c|}{ Variable } & \\
\hline DBE & $=1$ if the firm was listed as a certified DBE in all Unified Certification Program \\
& Directories \\
With DBE Goal & $=1$ if the contract has a DBE goal \\
Federal Funded & $=1$ if the contract is a federally funded project \\
\hline Contract over $\$ 4$ & $=1$ if the awarded contract amount is $\$ 4,000,000$ or more \\
million & \\
\hline Low risk & $=1$ if firm has low credit risk in the D\&B Hoover Database \\
Medium risk & $=1$ if firm has medium credit risk in the D\&B Hoover Database \\
High risk & $=1$ if firm has high credit risk in the D\&B Hoover Database \\
Credit missing & $=1$ if the firm's credit risk is missing in the D\&B Hoover Database \\
Construction & $=1$ if first two digits of firms' primary NAICS code is 23 \\
Waste Management & $=1$ if first two digits of firms' primary NAICS code is 56 \\
NAICS missing & $=1$ if the firm's two-digit NAICS code is missing \\
NJ & $=1$ if the firm is located in New Jersey \\
State missing & $=1$ if the firm's location is missing \\
Tenure & Number of years firm has been in business \\
Tenure missing & $=1$ if the firm's tenure is missing \\
Large size firm & $=1$ if the firm has more than 100 employees and total annual revenues are greater \\
& than $\$ 1$ million \\
Firm size is missing & $=1$ if the firm's size is missing \\
Number of Bids & Number of bids firm has submitted
\end{tabular}


The purely descriptive results from Tables $1-4$ do not account for relevant differences between DBEs and non-DBEs. Table 5 reports the definitions and Table 6 provides the descriptive statistics on the control variables used in our regression models. We create detailed measures of credit risk, tenure, location of firm, industry, type of contract, and number of bids. More than one third of the firms were rated by Dun \& Bradstreet as low risk. The average tenure of firms was 25 years, and about 30 percent were listed in construction. The majority of the firms were located in New Jersey but only 16 percent had 500 or more employees. More than three-quarters of the federal contracts had DBE goals attached to them. About one in five of the contracts were for $\$ 4$ million or more.

We also report in Table 6 the share of missing values for key independent variables. We report 645 bids and 250 bidders. The contract, bid and bidder characteristics are largely the same whether measured at the bidder level or at the bid level. Sixty percent of the firms had missing credit ratings and 30 percent had missing tenure, while 66 percent were missing firm size. The missing values were mostly from smaller and newer firms. Accordingly, we created a new variable denoting firms that were large, had good credit ratings, and which had been in business at least 10 years. The excluded group referenced smaller and newer firms and those with missing values on tenure, size or credit rating.

TABLE 6

SELECTED INDEPENDENT VARIABLES FOR BOTH DBES AND NON-DBES, FEDERALLY FUNDED CONTRACTS

\begin{tabular}{|c|c|c|c|c|c|c|}
\hline & \multicolumn{3}{|c|}{ Bid Level } & \multicolumn{3}{|c|}{ Bidder Level } \\
\hline & Mean & St. Dev. & $\mathbf{N}$ & Mean & St. Dev. & $\mathbf{N}$ \\
\hline \multicolumn{7}{|c|}{ Panel A: Independent Variables } \\
\hline $\begin{array}{ll}\text { Low risk } \\
\end{array}$ & 0.34 & 0.47 & 645 & 0.3 & 0.46 & 250 \\
\hline Medium risk & 0.03 & 0.16 & 645 & 0.02 & 0.15 & 250 \\
\hline High risk & 0.03 & 0.18 & 645 & 0.05 & 0.21 & 250 \\
\hline Tenure & 25.86 & 27.17 & 645 & 22.74 & 25.87 & 250 \\
\hline Construction & 0.29 & 0.45 & 645 & 0.34 & 0.47 & 211 \\
\hline Waste Management & 0.05 & 0.21 & 645 & 0.04 & 0.2 & 211 \\
\hline Other NAICS & 0.58 & 0.49 & 645 & 0.52 & 0.5 & 250 \\
\hline New Jersey State & 0.69 & 0.46 & 645 & 0.66 & 0.48 & 250 \\
\hline Large size firm & 0.16 & 0.37 & 645 & 0.1 & 0.3 & 250 \\
\hline With DBE Goal & 0.78 & 0.42 & 645 & 0.72 & 0.45 & 250 \\
\hline Contract over $\$ 4$ million & 0.19 & 0.4 & 645 & 0.2 & 0.4 & 250 \\
\hline Number of bids & 8.69 & 8.39 & 645 & & & \\
\hline \multicolumn{7}{|c|}{ Panel B: Share of Missing Values } \\
\hline Credit Rating & 0.6 & I & 645 & 0.63 & 0.48 & 250 \\
\hline Tenure & 0.3 & / & 645 & 0.32 & 0.47 & 250 \\
\hline Main NAICS Code & 0.09 & / & 645 & 0.16 & 0.36 & 250 \\
\hline State & 0 & / & 645 & 0.01 & 0.11 & 250 \\
\hline Firm size & 0.66 & / & 645 & 0.68 & 0.47 & 250 \\
\hline
\end{tabular}

\section{THE RESULTS AND DISCUSSION}

\section{Testing for Discrimination against Non-DBEs}

Appendix Table 1 presents the underlying estimates of equation 5, which tests the hypothesis that non-DBEs are discriminated against. We summarize the results in Table 7. The dependent variable is the bid success rate, estimated separately at the bid level and at the bidder level. Independent variables are number of bids; construction; DBE goal; and large, low risk, established firm. In some specifications, we 
also control for size of contract (amount over $\$ 4$ million) and include year fixed effects. Table 7 reports the coefficients on the non-DBE variable and the white male non-DBE variable for the linear probability model and the odds ratio from the logistic model.

At the bid level, none of the coefficients across the different model specifications and estimation methods are statistically significant for the non-DBE variable. The statistically insignificant but small negative coefficients and odds-ratios substantially less than one all signal the fact that non-DBEs do not have a significantly lower bid success rate than DBEs. The same result emerges when the effects of nonDBE status are measured at the bidder level.

Considering white male non-DBEs, Table 7 reveals a non-trivial advantage at the bid level. The coefficients on the white male non-DBE variable in each of the specifications are positive and statistically significant. For example, the odds of winning a contract are 1.8 to 2 times as high for white male non-DBEs as they are for other firms, whether one controls for size contract, firm characteristics, or year fixed effects. At the bidder level, the advantage of white male non-DBEs is diminishing and is not statistically significant. The odds of winning a contract at the bidder level falls to 1.28 to 1.36 times as high for white male non-DBEs as it is for others. Table 7 does not provide evidence of discrimination against non-DBEs or white male non-DBEs. If anything, the table suggests that white male non-DBEs experience favorable treatment on individual bids. Appendix Table 3 presents the underlying estimates of discrimination against white male non-DBEs.

\section{Testing for Non-DBE Discrimination Due to DBE Goals}

Appendix Table 2 presents the underlying estimates of equation 1, testing the hypothesis that nonDBEs are discriminated against because of DBE goals. We summarize the results in Table 8 . Table 8 reports the results of estimating the impacts of DBE goals on the bid success rates of non-DBEs and white male non-DBEs. The estimates are reported for a linear probability model and a logistic model. Specifications control for (1) number of bids, construction, and large, low risk, established firm; (2) number of bids, construction, large, low risk, established firm, and bid contract amount over $\$ 4$ million; (3) number of bids, construction, large, low risk, established firm and year fixed effects; and (4) number of bids, construction, large, low risk, established firm, and bid contract amount over $\$ 4$ million and year fixed effects. The table also reports the results measured at the bid level and at the bidder level. Appendix Table 4 presents the underlying estimates of discrimination against white male non-DBEs via DBE goals. 


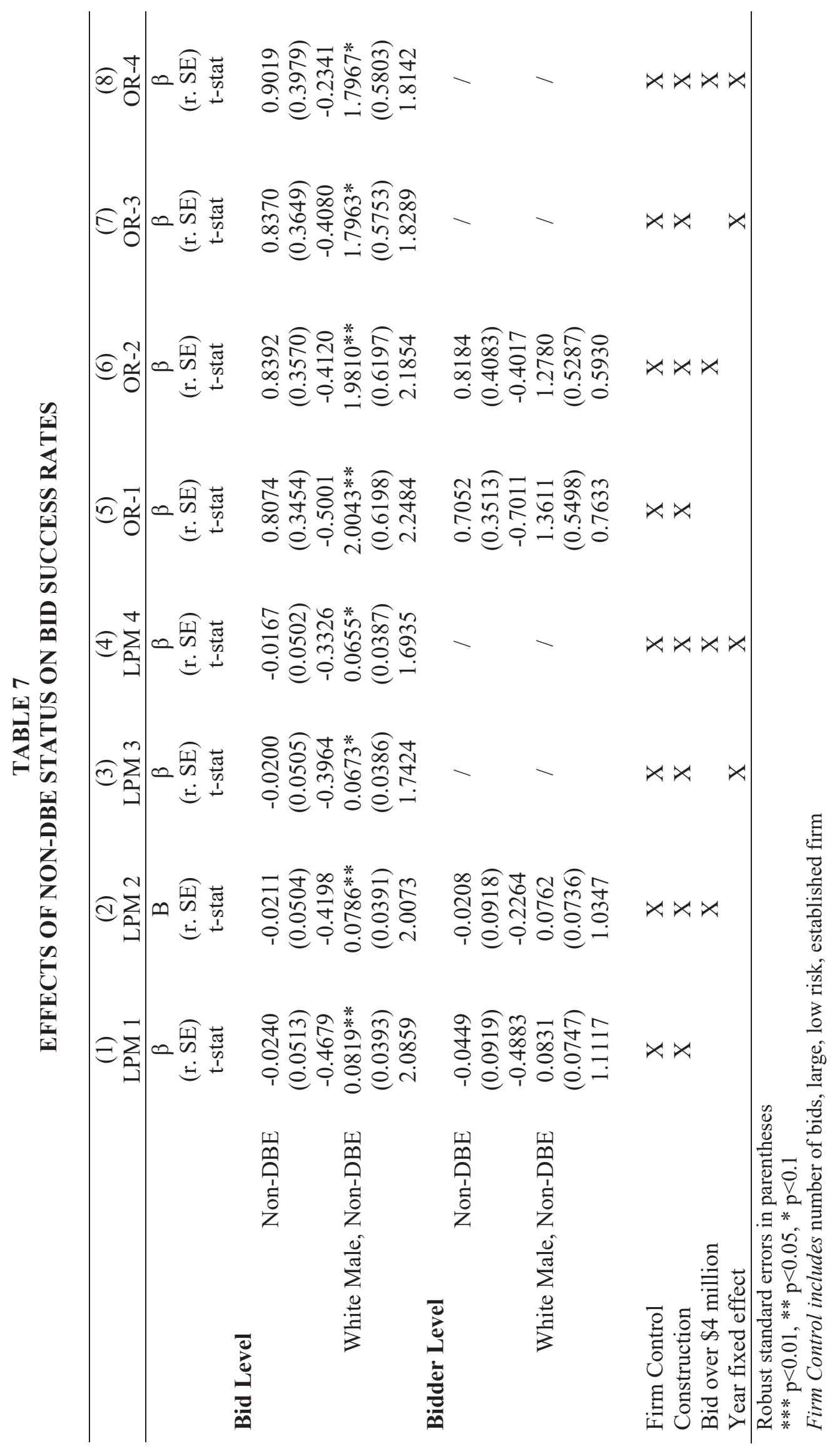

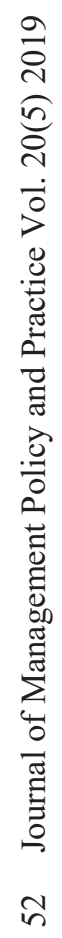




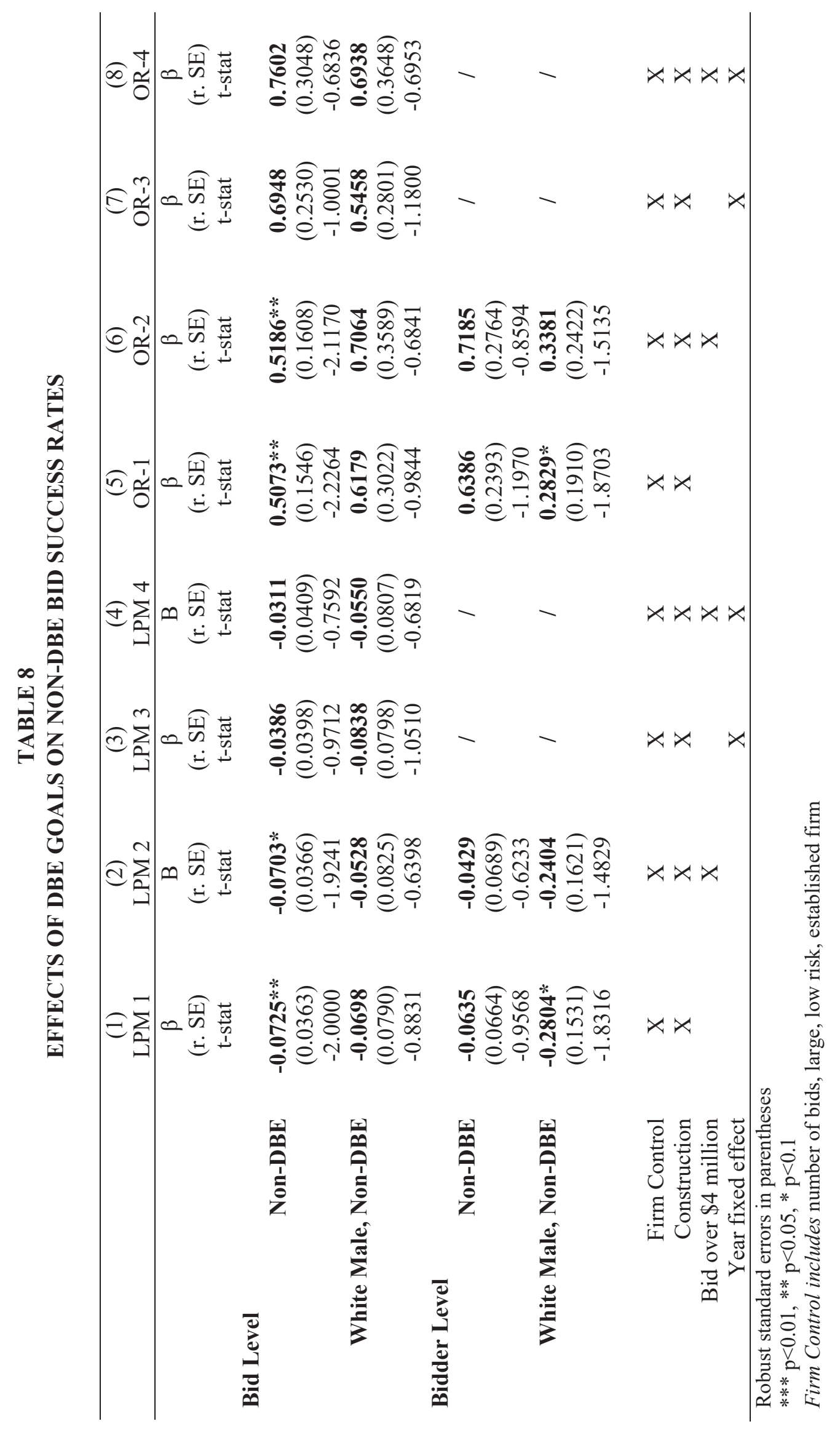


The results in Table 8 show that when controlling for type of contract, size of contract, and characteristics of the firm, there is no statistically significant impact of DBE goals on the bid success rates of white male non-DBEs at the bid level in either the linear probability model or the logistic model. Not taking into account the size of the contract and year fixed effect reveal a barely statistically significant effect of DBE goals on non-DBEs - which includes white males, white females who have graduate and minorities who are not certified as DBEs. Yet, even this impact disappears once one takes account of year fixed effects and size of contract. The negative effects of DBE goals on bid success rates of white male non-DBEs are barely significant at the 10 percent level and disappear once one controls for size of contract.

In short, there is virtually no evidence in the regression analysis of any discrimination against nonDBEs or white male non-DBE firms as a result of the DBE goal requirement on certain federal contracts. To explore the underlying dynamics of why white male non-DBEs might perceive that there is an adverse impact of DBE goals on their bid success rates, we can return to the descriptive evidence on bidding and contract awards. Tables 9 and 10 provide some further evidence.

Table 9 confirms the conventional wisdom among opponents to race-conscious programs that DBE goals result in lower success rates for white male non-DBEs. Without goals, the average bid success rate at the bid level is 15 percent. With goals, the success rate for white male non-DBEs is only 8 percent. At the bidder level, the difference is also stark. The success rate for white male non-DBEs is 54 percent when there are no DBE goals but only 28 percent when there are DBE goals, when measured at the bidder level, but blaming the disparity on DBEs is mistaken. Disadvantaged business enterprise also experience higher success rates without goals than with goals at the bid level. The small number of DBEs, however, renders the difference statistically insignificant. Of course, the purely descriptive results in Table 9 do not account for firm characteristics, contract size, or year fixed effects. Nonetheless, these descriptive results help to frame why and how white male-owned firms mistakenly believe that the DBE goals discriminate against them.

TABLE 9

MEAN BID SUCCESS RATE FEDERALLY FUNDED CONTRACTS

\begin{tabular}{rcccc}
\hline & All & DBE & Non-DBE & White Male Non-DBE \\
\hline BID LEVEL & & & & \\
With DBE Goals & 0.102 & 0.111 & 0.101 & 0.081 \\
$\mathrm{n}=$ & 502 & 36 & 466 & 333 \\
Without DBE Goals & 0.168 & 0.231 & 0.162 & 0.153 \\
$\mathrm{n}=$ & 143 & 13 & 130 & 111 \\
T-Stat & $-1.94^{*}$ & -1.047 & $-1.720^{*}$ & $-1.924^{*}$ \\
& & & & \\
BIDDER LEVEL $\quad$ & & & & 0.278 \\
With DBE Goals & 0.227 & 0.286 & 0.222 & 54 \\
$\mathrm{n}=$ & 181 & 14 & 167 & 0.538 \\
Without DBE Goals & 0.246 & 0.200 & 0.254 & 13 \\
$\mathrm{n}=$ & 69 & 10 & 59 & $-1.814^{*}$ \\
T-Stat & -0.331 & 0.460 & -0.511 & \\
\hline
\end{tabular}

Yet, even if white male non-DBEs have lower bid success rates when bidding on projects that have DBE goals, does that mean that on average white male non-DBEs are harmed by the imposition of these goals? To answer this question, one must examine the payoffs associated with winning contracts with goals vs. those without goals.

54 Journal of Management Policy and Practice Vol. 20(5) 2019 
As Table 10 shows, there are enormous differences in the size of contracts won with goals vs. those without goals. The mean contract award to non-DBEs bidding on contracts with goals was $\$ 8$ million while the mean contract award to non-DBEs bidding on contracts without goals was only $\$ 474,000$. Across both the bid level and bidder level, and for white male non-DBEs, DBEs and all firms, the award amounts were higher for contracts with goals. Thus, the illusion that non-DBEs are discriminated against as a result of DBE goals is shattered by the reality that the lower success rates experienced when bidding on contracts with goals is off-set by the higher payoff associated with contracts with goals.

\section{SUMMARY AND CONCLUSIONS}

In this paper, we have tested the hypothesis that non-DBEs are discriminated against in public procurement and contracting and that the mechanism by which this discrimination occurs is the DBE goal requirement. We have used data from 2007-2013 from New Jersey Transit Corporation, the third largest transit authority in the United States. Our central conclusion is that the contention that federal DBE goals discriminate against non-DBEs is not supported by the analysis. More intuitively, all firms - whether nonDBEs or DBEs - have lower success rates on federal contracts with goals.

TABLE 10

MEAN CONTRACT AWARD AMOUNTS FEDERALLY FUNDED CONTRACTS

\begin{tabular}{|c|c|c|c|c|}
\hline & All & DBEs & Non-DBEs & White Male Non-DBEs \\
\hline \multicolumn{5}{|l|}{ BID LEVEL } \\
\hline With DBE Goals & $\$ 7,473,900$ & $\$ 1,181,500$ & $\$ 8,009,424$ & $\$ 9,384,166$ \\
\hline $\mathrm{n}=$ & 51 & 4 & 47 & (4) \\
\hline Without DBE Goals & $\$ 504,455$ & $\$ 715,797$ & $\$ 474,263$ & $\$ 357,339$ \\
\hline $\mathrm{n}=$ & 24 & 3 & 21 & 17 \\
\hline t-Stat & $2.219^{* *}$ & 0.756 & $2.217 * *$ & $1.634 * *$ \\
\hline \multicolumn{5}{|l|}{ BIDDER LEVEL } \\
\hline With DBE Goals & $\$ 6,479,051$ & $\$ 1,205,893$ & $\$ 7,049,122$ & $\$ 8,486,038$ \\
\hline $\mathrm{n}=$ & 41 & 4 & 37 & 26 \\
\hline Without DBE Goals & $\$ 438,459$ & $\$ 994,221$ & $\$ 364,358$ & $\$ 332,741$ \\
\hline $\mathrm{n}=$ & 17 & 2 & 15 & 10 \\
\hline t-Stat & $1.650 *$ & 0.225 & $1.651 *$ & 1.417 \\
\hline
\end{tabular}

One of the reasons why non-DBEs, and white male non-DBEs in particular, believe or perceive that there is discrimination against them stemming from the imposition of DBE goals is that goals are typically set on larger contracts, and small businesses - whether white male owned or minority owned are less successful in winning these larger contracts than on contracts without goals. Two empirical questions then emerge in light of these beliefs or perceptions from some non-DBEs. The first is controlling for size of contract, presence of DBE goals and firm characteristics, is the success rate for non-DBEs lower than DBEs? In fact, non-DBEs have higher bid success rates than DBEs, even though these differences are not statistically significant. The descriptive results in Table 1 alone may be sufficient to cause a non-DBE plaintiff's allegation of discrimination to be dismissed, but such a plaintiff could pursue a claim that it is the DBE program itself that discriminates against non-DBEs. Indeed, the descriptive results do show that non-DBEs competing for contracts with DBE goals are less successful than non-DBEs competing for contracts without goals. This leads to the second empirical question controlling for size of contract and firm characteristics do non-DBEs competing for contracts without DBE goals have higher success rates than non-DBEs competing for contracts with DBE goals? Our results show that once one controls for contract size, any appearance of discrimination against non-DBEs arising from DBE goals vanishes. In short, the evidence does not support the view that non-DBEs are 
discriminated against or that DBE goals themselves are a source of discrimination against non-DBEs or white males.

There are several limitations of our analysis. The first is that the data used comes from New Jersey Transit, one of the largest transit authorities in the country that has successfully weathered many lawsuits over the years relating to its DBE programs. The experience and sophistication of NJT's procurement and contracting produces an awareness and proactive efforts to minimize potential claims against the corporation. Although the conclusions we reach in this instance mirror those in the Geyer case, we cannot conclude that the same results would emerge in other jurisdictions.

A second limitation is that we do not have enough observations and enough valid, non-missing values to estimate the preferred models in equations 2 - 4, which account for interactions between non-DBE status and all other variables in the model. Thus, the results obtained constrain the findings to instances where there are no interaction effects.

Finally, the data used comes from a post-recession era and overlapped with Hurricane Sandy, one of the most destructive storms to ever affect the New York and New Jersey area. Two important facts about the post-Hurricane Sandy clean-up are: (a) the billions of dollars of emergency federal aid awarded to New Jersey and other states; and (b) the waiver of MBE/WBE goals in New York during the hurricane cleanup. The waivers increase the chances of success for non-DBEs in a nearby state reducing the likelihood of even bidding on contracts with NJT, which could further affect the bid success rates for nonDBEs. Year fixed effects only partially accounts for these events and may not account for switching bids from one jurisdiction to another.

Perceptions and beliefs still matter, however. The DBE goals program is a form of affirmative action. Like many other race-conscious remedies, there is a narrative that the remedy hurts white males or in this case non-DBEs. At least as it relates to bid success rates, our findings - mirroring those from previous studies -- show just the opposite (Myers and Chan, 1997). Federal DBE goals set on large contracts appear to provide significant benefits to non-DBEs. Although bid success rates may be lower for nonDBEs competing for contracts that have goals vs. contracts without goals, the payoff to non-DBEs from contracts with goals is many times higher than the payoffs from contracts without goals. Perhaps the opposition to the DBE goals program among non-DBEs can be addressed by greater transparency about the net benefits of the program to firms that are not certified DBEs. 


\section{REFERENCES}

City of Richmond v. J.A. Croson Co., 488 U.S. 469. (1989).

De Silva, D. G., Dunne, T., Kosmopoulou, G., \& Lamarche, C. (2012). Disadvantaged Business Enterprise goals in government procurement contracting: an analysis of bidding behavior and costs. International Journal of Industrial Organization, 30(4), 377-388.

De Silva, D. G., Hubbard, T.P., \& Kosmopoulou, G. (2019). An Evaluation of a Bidder Training Program. Retrieved from https://ssrn.com/abstract=2351808.

Geyer Signal, Inc. et al v. Minnesota Department of Transportation et al, No. 0:2011 cv00321 - Document 112 (D. Minn.). (2014).

Gooden, S.T., \& Myers, S.L. Jr. (2018). The Kerner Commission Report Fifty Years Later: Revisiting the American Dream. RSF: The Russell Sage Foundation Journal of the Social Sciences, 4(6), 117.

Kerner, O., Kerner, \& Wicker, T. (1968). Report of the National Advisory Commission on Civil Disorders: Special Introduction by Tom Wicker of The New York Times. National Advisory Commission on Civil Disorders, NY: Bantam Books.

Marion, J. (2017). Affirmative action exemptions and capacity constrained firms. American Economic Journal: Economic Policy, 9(3), 377-407.

Marion, J. (2011). Affirmative Action and the Utilization of Minority-and Women-Owned Businesses in Highway Procurement. Economic Inquiry, 49(3), 899-915.

Marion, J. (2009). How costly is affirmative action? Government contracting and California's Proposition 209. The Review of Economics and Statistics, 91(3), 503-522.

Myers, S.L. Jr. (2013, March 1). Rebuttal Report of Defendants' Expert, Civil Action No. 11-321. Geyer Signal, Inc. and Kevin Kissner, Plaintiffs v. Minnesota Department of Transportation, et al., Defendants.

Myers, S.L. Jr. (2013, May 13). Second Rebuttal Report of Defendants' Expert”, Civil Action No. 11-321. Geyer Signal, Inc. and Kevin Kissner, Plaintiffs v. Minnesota Department of Transportation, et al., Defendants.

Myers, S.L. Jr. (2013, December 31). Initial Report of Defendant's Expert”, Civil Action No. 11-321. Geyer Signal, Inc. and Kevin Kissner, Plaintiffs v. Minnesota Department of Transportation, et al., Defendants.

Myers, S.L. Jr., \& Chan, T. (1997). Who Benefits from Minority Business Set-Asides? The Case of New Jersey. Journal of Policy Analysis and Management, 15(2), 202-226.

Myers, S.L. Jr., \& Ha, I. (2018). Race Neutrality: Rationalizing Remedies to Racial Inequality. Lanham, MD: Lexington Books.

New Transit Corporation. (n.d.). Retrieved from https://www.njtransit.com/tm/tm_servlet.srv?hdnPageAction=CorpInfoTo

Rosa, B.V. (2018). Subcontracting Requirements and the Cost of Government Procurement (Doctoral dissertation). Available from ProQuest Dissertations and Theses database. (UMI No. 10789235) 


\section{APPENDIX}

TABLE 1-A

ESTIMATES OF DISCRIMINATION AGAINST NON-DBES

\begin{tabular}{|c|c|c|c|c|c|c|}
\hline & \multicolumn{6}{|c|}{ Bid Level } \\
\hline & (1) & (2) & (3) & (4) & $(5)$ & (6) \\
\hline & LPM 1 & LPM 2 & LPM 3 & LPM 4 & Logistics 1 & Logistics 2 \\
\hline & $\beta$ & $\beta$ & $\beta$ & $\beta$ & Odds Ratio & Odds Ratio \\
\hline & (r. SE) & (r. SE) & (r. SE) & (r. SE) & (r. SE) & (r. SE) \\
\hline & T-stat & T-stat & T-stat & T-stat & Z-score & Z-score \\
\hline \multirow[t]{3}{*}{ NAICS23 (construction) } & $0.0689 * *$ & $0.0893 * *$ & 0.0318 & 0.0574 & $1.8585^{* *}$ & $2.3098 * * *$ \\
\hline & $(0.0324)$ & $(0.0353)$ & $(0.0332)$ & $(0.0362)$ & $(0.4986)$ & $(0.6988)$ \\
\hline & 2.1290 & 2.5255 & 0.9553 & 1.5829 & 2.3098 & 2.7673 \\
\hline \multirow{4}{*}{$\begin{array}{l}\text { Large, Low risk and established at } \\
\text { least } 10 \text { years }\end{array}$} & & & & & & \\
\hline & 0.0107 & 0.0187 & 0.0169 & 0.0238 & 1.1125 & 1.1898 \\
\hline & $(0.0414)$ & $(0.0426)$ & $(0.0416)$ & $(0.0423)$ & $(0.4411)$ & $(0.4895)$ \\
\hline & 0.2584 & 0.4393 & 0.4054 & 0.5619 & 0.2688 & 0.4223 \\
\hline \multirow[t]{3}{*}{ Number of Bids } & -0.0022 & -0.0017 & -0.0020 & -0.0017 & 0.9788 & 0.9837 \\
\hline & $(0.0014)$ & $(0.0014)$ & $(0.0014)$ & $(0.0014)$ & $(0.0144)$ & $(0.0144)$ \\
\hline & -1.5970 & -1.2142 & -1.4241 & -1.2325 & -1.4558 & -1.1204 \\
\hline \multirow[t]{3}{*}{ Non-DBE } & -0.0240 & -0.0211 & -0.0200 & -0.0167 & 0.8074 & 0.8392 \\
\hline & $(0.0513)$ & $(0.0504)$ & $(0.0505)$ & $(0.0502)$ & $(0.3454)$ & $(0.3570)$ \\
\hline & -0.4679 & -0.4198 & -0.3964 & -0.3326 & -0.5001 & -0.4120 \\
\hline \multirow[t]{3}{*}{ Contract with DBE goal } & & $-0.0770 * *$ & & -0.0419 & & $0.4913 * *$ \\
\hline & & $(0.0353)$ & & $(0.0400)$ & & $(0.1448)$ \\
\hline & & -2.1807 & & -1.0461 & & -2.4121 \\
\hline \multicolumn{7}{|l|}{ Biding contract amount is over $\$ 4$} \\
\hline \multirow[t]{3}{*}{ million } & & -0.0221 & & -0.0381 & & 0.8219 \\
\hline & & $(0.0372)$ & & $(0.0409)$ & & $(0.3109)$ \\
\hline & & -0.5930 & & -0.9305 & & -0.5184 \\
\hline \multirow[t]{3}{*}{ Year of 2008} & & & -0.0084 & -0.0362 & & \\
\hline & & & $(0.0668)$ & $(0.0593)$ & & \\
\hline & & & -0.1261 & -0.6105 & & \\
\hline \multirow[t]{3}{*}{ Year of 2009} & & & -0.0686 & $-0.0897 *$ & & \\
\hline & & & $(0.0538)$ & $(0.0504)$ & & \\
\hline & & & -1.2742 & -1.7782 & & \\
\hline \multirow[t]{3}{*}{ Year of 2010} & & & 0.0651 & & & \\
\hline & & & $(0.0841)$ & & & \\
\hline & & & 0.7740 & & & \\
\hline \multirow[t]{3}{*}{ Year of 2011} & & & -0.0096 & -0.0540 & & \\
\hline & & & $(0.0735)$ & $(0.0700)$ & & \\
\hline & & & -0.1310 & -0.7716 & & \\
\hline \multirow[t]{3}{*}{ Year of 2012} & & & 0.1981 & 0.1579 & & \\
\hline & & & $(0.1257)$ & $(0.1270)$ & & \\
\hline & & & 1.5761 & 1.2431 & & \\
\hline \multirow[t]{3}{*}{ Constant } & $0.1366^{* * *}$ & $0.1868^{* * *}$ & $0.1781 * * *$ & $0.2023 * * *$ & $0.1545^{* * *}$ & $0.2313 * * *$ \\
\hline & $(0.0486)$ & $(0.0555)$ & $(0.0683)$ & $(0.0724)$ & $(0.0621)$ & $(0.1001)$ \\
\hline & 2.8099 & 3.3659 & 2.6083 & 2.7938 & -4.6479 & -3.3838 \\
\hline Observations & 645 & 645 & 645 & 645 & 645 & 645 \\
\hline F statistic & 1.354 & 1.807 & 1.725 & 1.655 & & \\
\hline Prob $>$ F & 0.248 & 0.0952 & 0.0801 & 0.0799 & & \\
\hline Adjusted R-Squared & 0.00994 & 0.0114 & 0.0230 & 0.0243 & & \\
\hline chi squared & & & & & 6.209 & 12.24 \\
\hline Prob $>$ Fchi 2 & & & & & 0.184 & 0.0568 \\
\hline Pseudo R-Squared & & & & & 0.0132 & 0.0276 \\
\hline
\end{tabular}

Robust standard errors in parentheses

$* * * \mathrm{p}<0.01, * * \mathrm{p}<0.05, * \mathrm{p}<0.1$ 
TABLE 1-B

ESTIMATES OF DISCRIMINATION AGAINST NON-DBES

\begin{tabular}{|c|c|c|c|c|c|c|}
\hline & \multicolumn{2}{|c|}{ Bid Level } & \multicolumn{4}{|c|}{ Bidder Level } \\
\hline & (1) & (2) & (3) & (4) & $(5)$ & (6) \\
\hline & Logistics 3 & Logistics 4 & LPM 5 & LPM 6 & Logistics 5 & Logistics 6 \\
\hline & Odds Ratio & Odds Ratio & $\beta$ & $\beta$ & Odds Ratio & Odds Ratio \\
\hline & (r. SE) & (r. SE) & (r. SE) & (r. SE) & (r. SE) & (r. SE) \\
\hline & Z-score & Z-score & T-stat & T-stat & Z-score & Z-score \\
\hline \multirow[t]{3}{*}{ NAICS23 (construction) } & 1.3507 & $1.7257^{*}$ & 0.0672 & $0.1194 *$ & 1.2927 & 1.7685 \\
\hline & $(0.3925)$ & $(0.5662)$ & $(0.0614)$ & $(0.0677)$ & $(0.4382)$ & $(0.6719)$ \\
\hline & 1.0347 & 1.6630 & 1.0956 & 1.7637 & 0.7574 & 1.5006 \\
\hline \multirow{3}{*}{$\begin{array}{l}\text { Large, Low risk and established } \\
\text { at least } 10 \text { years }\end{array}$} & 1.1735 & 1.2618 & $0.2157^{*}$ & $0.2250^{*}$ & $2.4390 *$ & $2.6313^{*}$ \\
\hline & $(0.4728)$ & $(0.5195)$ & $(0.1246)$ & $(0.1220)$ & $(1.2734)$ & $(1.3649)$ \\
\hline & 0.3971 & 0.5649 & 1.7307 & 1.8448 & 1.7077 & 1.8652 \\
\hline \multirow[t]{3}{*}{ Number of Bids } & 0.9805 & 0.9831 & $0.0015^{* * *}$ & $0.0014 * * *$ & $1.0512 *$ & $1.0543 *$ \\
\hline & $(0.0142)$ & $(0.0145)$ & $(0.0003)$ & $(0.0003)$ & $(0.0289)$ & $(0.0286)$ \\
\hline & -1.3550 & -1.1595 & 5.8849 & 5.1975 & 1.8181 & 1.9491 \\
\hline \multirow[t]{3}{*}{ Non-DBE } & 0.8370 & 0.9019 & -0.0449 & -0.0208 & 0.7052 & 0.8184 \\
\hline & $(0.3649)$ & $(0.3979)$ & $(0.0919)$ & $(0.0918)$ & $(0.3513)$ & $(0.4083)$ \\
\hline & -0.4080 & -0.2341 & -0.4883 & -0.2264 & -0.7011 & -0.4017 \\
\hline \multirow[t]{3}{*}{ Contract with DBE goal } & & 0.7105 & & -0.0321 & & 0.7542 \\
\hline & & $(0.2722)$ & & $(0.0646)$ & & $(0.2753)$ \\
\hline & & -0.8922 & & -0.4973 & & -0.7730 \\
\hline \multirow{3}{*}{$\begin{array}{l}\text { Biding contract amount is over } \$ 4 \\
\text { million }\end{array}$} & & 0.6993 & & $-0.1188^{*}$ & & 0.4783 \\
\hline & & $(0.3052)$ & & $(0.0697)$ & & $(0.2287)$ \\
\hline & & -0.8196 & & -1.7049 & & -1.5425 \\
\hline \multirow[t]{3}{*}{ Year of 2008} & 0.9216 & 0.8966 & & & & \\
\hline & $(0.4665)$ & $(0.4529)$ & & & & \\
\hline & -0.1614 & -0.2160 & & & & \\
\hline \multirow[t]{3}{*}{ Year of 2009} & 0.5071 & 0.5170 & & & & \\
\hline & $(0.2215)$ & $(0.2531)$ & & & & \\
\hline & -1.5546 & -1.3476 & & & & \\
\hline \multirow[t]{3}{*}{ Year of 2010} & 1.5233 & 1.3704 & & & & \\
\hline & $(0.8296)$ & $(0.7694)$ & & & & \\
\hline & 0.7729 & 0.5612 & & & & \\
\hline \multirow[t]{3}{*}{ Year of 2011} & 0.9227 & 0.7515 & & & & \\
\hline & $(0.5163)$ & $(0.4558)$ & & & & \\
\hline & -0.1438 & -0.4711 & & & & \\
\hline \multirow[t]{3}{*}{ Year of 2012} & $3.0024 *$ & 2.5806 & & & & \\
\hline & (1.9014) & (1.8099) & & & & \\
\hline & 1.7360 & 1.3517 & & & & \\
\hline \multirow[t]{3}{*}{ Constant } & $0.2239 * * *$ & $0.2646^{* *}$ & $0.2282 * * *$ & $0.2392 * * *$ & $0.2630 * * *$ & $0.2871 * *$ \\
\hline & $(0.1228)$ & $(0.1487)$ & $(0.0869)$ & $(0.0913)$ & $(0.1226)$ & $(0.1406)$ \\
\hline & -2.7292 & -2.3658 & 2.6257 & 2.6195 & -2.8649 & -2.5490 \\
\hline Observations & 645 & 645 & 250 & 250 & 250 & 250 \\
\hline F statistic & & & 11.85 & 8.224 & & \\
\hline Prob $>$ F & & & $8.07 \mathrm{e}-09$ & $4.10 \mathrm{e}-08$ & & \\
\hline Adjusted R-Squared & & & 0.0416 & 0.0312 & & \\
\hline chi squared & 20.99 & 24.63 & & & 9.109 & 12.63 \\
\hline Prob $>$ Fchi 2 & 0.0127 & 0.0103 & & & 0.0584 & 0.0494 \\
\hline Pseudo R-Squared & 0.0437 & 0.0493 & & & 0.0460 & 0.0601 \\
\hline
\end{tabular}

Robust standard errors in parentheses

$* * * \mathrm{p}<0.01, * * \mathrm{p}<0.05, * \mathrm{p}<0.1$ 
TABLE 2-A

ESTIMATES OF DISCRIMINATION VIA DBE GOALS

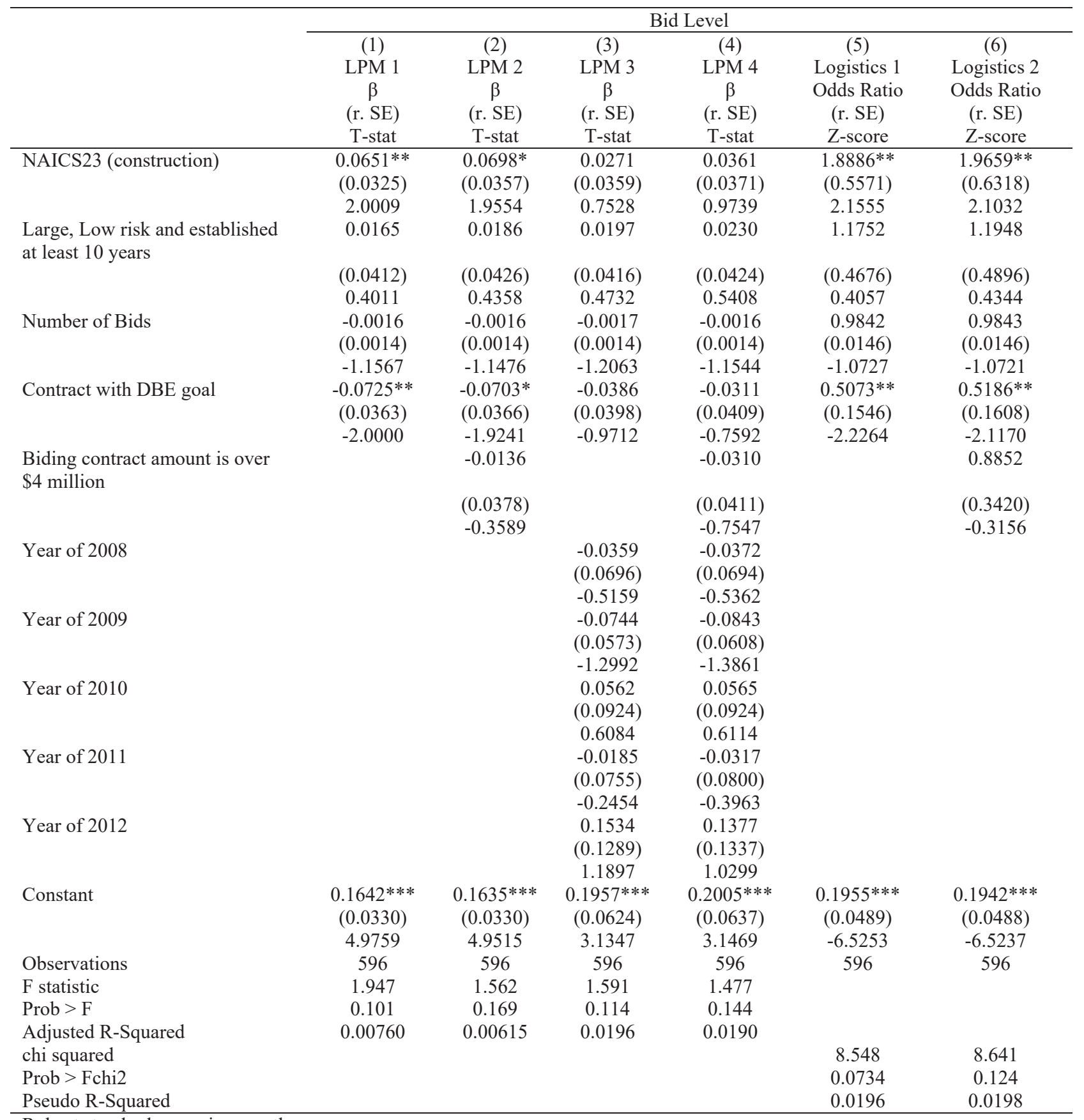

Robust standard errors in parentheses

$* * * \mathrm{p}<0.01, * * \mathrm{p}<0.05, * \mathrm{p}<0.1$ 
TABLE 2-B

ESTIMATES OF DISCRIMINATION VIA DBE GOALS

\begin{tabular}{|c|c|c|c|c|c|c|}
\hline & \multicolumn{2}{|c|}{ Bid Level } & \multicolumn{4}{|c|}{ Bidder Level } \\
\hline & $(1)$ & $(2)$ & (3) & (4) & $(5)$ & $(6)$ \\
\hline & Logistics 3 & Logistics 4 & LPM 5 & LPM 6 & Logistics 5 & Logistics 6 \\
\hline & $\begin{array}{l}\text { Odds Ratio } \\
\text { (r. SE) }\end{array}$ & $\begin{array}{l}\text { Odds Ratio } \\
\text { (r. SE) }\end{array}$ & $\begin{array}{c}\beta \\
\text { (r. SE) }\end{array}$ & $\begin{array}{c}\beta \\
\text { (r. SE) }\end{array}$ & $\begin{array}{l}\text { Odds Ratio } \\
\text { (r. SE) }\end{array}$ & $\begin{array}{l}\text { Oddds Ratio } \\
\text { (r. SE) }\end{array}$ \\
\hline \multirow[t]{3}{*}{ NAICS23 (construction) } & 1.3351 & 1.4347 & 0.0573 & 0.0933 & 1.2388 & 1.5245 \\
\hline & $(0.4588)$ & $(0.5012)$ & $(0.0648)$ & $(0.0704)$ & $(0.4626)$ & $(0.6175)$ \\
\hline & 0.8410 & 1.0332 & 0.8843 & 1.3256 & 0.5733 & 1.0410 \\
\hline \multirow{4}{*}{$\begin{array}{l}\text { Large, Low risk and established } \\
\text { at least } 10 \text { years }\end{array}$} & & & & & & \\
\hline & 1.2097 & 1.2504 & $0.2216^{*}$ & $0.2265^{*}$ & $2.5240^{*}$ & $2.6443 *$ \\
\hline & $(0.4897)$ & $(0.5159)$ & $(0.1239)$ & $(0.1227)$ & $(1.3106)$ & $(1.3713)$ \\
\hline & 0.4703 & 0.5416 & 1.7892 & 1.8460 & 1.7832 & 1.8751 \\
\hline \multirow[t]{3}{*}{ Number of Bids } & 0.9834 & 0.9837 & $0.0015^{* * *}$ & $0.0015^{* * *}$ & $1.0535^{*}$ & $1.0525 *$ \\
\hline & $(0.0147)$ & $(0.0147)$ & $(0.0003)$ & $(0.0003)$ & $(0.0290)$ & $(0.0279)$ \\
\hline & -1.1183 & -1.1034 & 6.0845 & 5.5174 & 1.8942 & 1.9337 \\
\hline \multirow[t]{3}{*}{ Contract with DBE goal } & 0.6948 & 0.7602 & -0.0635 & -0.0429 & 0.6386 & 0.7185 \\
\hline & $(0.2530)$ & $(0.3048)$ & $(0.0664)$ & $(0.0689)$ & $(0.2393)$ & $(0.2764)$ \\
\hline & -1.0001 & -0.6836 & -0.9568 & -0.6233 & -1.1970 & -0.8594 \\
\hline \multicolumn{7}{|l|}{ Biding contract amount is over } \\
\hline \multirow[t]{3}{*}{$\$ 4$ million } & & 0.7434 & & -0.1004 & & 0.5371 \\
\hline & & $(0.3292)$ & & $(0.0725)$ & & $(0.2617)$ \\
\hline & & -0.6695 & & -1.3844 & & -1.2755 \\
\hline \multirow[t]{3}{*}{ Year of 2008} & 0.7451 & 0.7408 & & & & \\
\hline & $(0.3976)$ & $(0.3934)$ & & & & \\
\hline & -0.5514 & -0.5650 & & & & \\
\hline \multirow[t]{3}{*}{ Year of 2009} & 0.4931 & 0.4478 & & & & \\
\hline & $(0.2234)$ & $(0.2234)$ & & & & \\
\hline & -1.5610 & -1.6101 & & & & \\
\hline \multirow[t]{3}{*}{ Year of 2010} & 1.3776 & 1.3837 & & & & \\
\hline & $(0.7969)$ & $(0.8041)$ & & & & \\
\hline & 0.5538 & 0.5589 & & & & \\
\hline \multirow[t]{3}{*}{ Year of 2011} & 0.8477 & 0.7550 & & & & \\
\hline & $(0.4730)$ & $(0.4567)$ & & & & \\
\hline & -0.2961 & -0.4645 & & & & \\
\hline \multirow[t]{3}{*}{ Year of 2012} & 2.4422 & 2.1253 & & & & \\
\hline & $(1.6529)$ & $(1.5556)$ & & & & \\
\hline & 1.3193 & 1.0300 & & & & \\
\hline \multirow[t]{3}{*}{ Constant } & $0.2568 * * *$ & $0.2663 * * *$ & $0.2324 * * *$ & $0.2294 * * *$ & $0.2570 * * *$ & $0.2519 * * *$ \\
\hline & $(0.1169)$ & $(0.1234)$ & $(0.0562)$ & $(0.0563)$ & $(0.0801)$ & $(0.0788)$ \\
\hline & -2.9862 & -2.8561 & 4.1367 & 4.0725 & -4.3614 & -4.4056 \\
\hline Observations & 596 & 596 & 226 & 226 & 226 & 226 \\
\hline F statistic & & & 11.89 & 10.19 & & \\
\hline Prob $>$ F & & & $9.04 \mathrm{e}-09$ & $8.59 \mathrm{e}-09$ & & \\
\hline Adjusted R-Squared & & & 0.0285 & 0.0316 & & \\
\hline chi squared & 18.94 & 19.95 & & & 9.368 & 11.15 \\
\hline Prob $>$ Fchi 2 & 0.0257 & 0.0297 & & & 0.0525 & 0.0484 \\
\hline Pseudo R-Squared & 0.0424 & 0.0437 & & & 0.0513 & 0.0585 \\
\hline
\end{tabular}

Robust standard errors in parentheses

$* * * \mathrm{p}<0.01, * * \mathrm{p}<0.05, * \mathrm{p}<0.1$ 
TABLE 3-A

ESTIMATES OF DISCRIMINATION AGAINST WHITE MALE NON-DBES

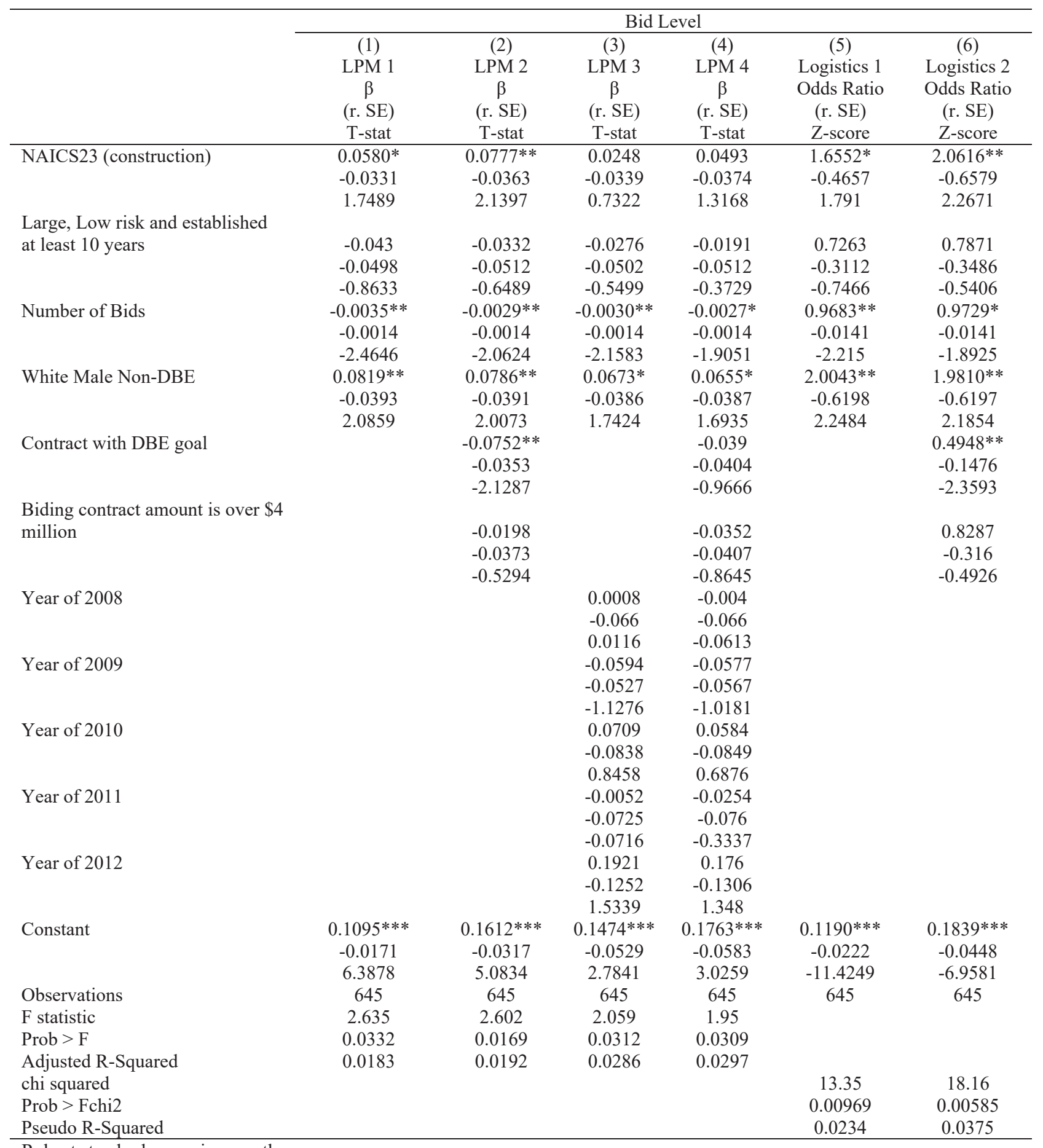

Robust standard errors in parentheses

$* * * \mathrm{p}<0.01, * * \mathrm{p}<0.05, * \mathrm{p}<0.1$ 
TABLE 3-B

ESTIMATES OF DISCRIMINATION AGAINST WHITE MALE NON-DBES

\begin{tabular}{|c|c|c|c|c|c|c|}
\hline & \multicolumn{2}{|c|}{ Bid Level } & \multicolumn{4}{|c|}{ Bidder Level } \\
\hline & (1) & $(2)$ & $(3)$ & $(4)$ & $(5)$ & (6) \\
\hline & Logistics 3 & Logistics 4 & LPM 5 & LPM 6 & Logistics 5 & Logistics 6 \\
\hline & $\begin{array}{l}\text { Odds Ratio } \\
\text { (r. SE) }\end{array}$ & $\begin{array}{l}\text { Odds Ratio } \\
\text { (r. SE) }\end{array}$ & $\begin{array}{c}\beta \\
\text { (r. } \mathrm{SE} \text { ) }\end{array}$ & $\begin{array}{c}\beta \\
\text { (r. } \mathrm{SE})\end{array}$ & $\begin{array}{l}\text { Odds Ratio } \\
\text { (r. SE) }\end{array}$ & $\begin{array}{l}\text { Odds Ratio } \\
\text { (r. SE) }\end{array}$ \\
\hline \multirow[t]{3}{*}{ NAICS23 (construction) } & 1.2327 & 1.5801 & 0.0454 & 0.0987 & 1.2150 & 1.6873 \\
\hline & -0.3754 & -0.5491 & $(0.0667)$ & $(0.0726)$ & $(0.4392)$ & $(0.6810)$ \\
\hline & 0.6869 & 1.3165 & 0.6804 & 1.3596 & 0.5387 & 1.2963 \\
\hline \multirow{4}{*}{$\begin{array}{l}\text { Large, Low risk and established } \\
\text { at least } 10 \text { years }\end{array}$} & & & & & & \\
\hline & 0.8141 & 0.8785 & 0.1537 & 0.1702 & 1.9575 & 2.2194 \\
\hline & -0.3613 & -0.3981 & $(0.1346)$ & $(0.1314)$ & $(1.1046)$ & $(1.2553)$ \\
\hline & -0.4635 & -0.2859 & 1.1419 & 1.2952 & 1.1903 & 1.4096 \\
\hline \multirow[t]{3}{*}{ Number of Bids } & $0.9720 * *$ & $0.9747 *$ & $0.0015^{* * *}$ & $0.0014 * * *$ & 1.0436 & $1.0485^{*}$ \\
\hline & -0.0137 & -0.0139 & $(0.0002)$ & $(0.0003)$ & $(0.0285)$ & $(0.0287)$ \\
\hline & -2.0076 & -1.7975 & 6.6284 & 5.7240 & 1.5617 & 1.7301 \\
\hline \multirow[t]{3}{*}{ White Male Non-DBE } & $1.7963^{*}$ & $1.7967 *$ & 0.0831 & 0.0762 & 1.3611 & 1.2780 \\
\hline & -0.5753 & -0.5803 & $(0.0747)$ & $(0.0736)$ & $(0.5498)$ & $(0.5287)$ \\
\hline & 1.8289 & 1.8142 & 1.1117 & 1.0347 & 0.7633 & 0.5930 \\
\hline \multirow[t]{3}{*}{ Contract with DBE goal } & & 0.6966 & & -0.0362 & & 0.7471 \\
\hline & & -0.2648 & & $(0.0641)$ & & $(0.2727)$ \\
\hline & & -0.9511 & & -0.5659 & & -0.7987 \\
\hline \multicolumn{7}{|l|}{ Biding contract amount is over } \\
\hline \multirow[t]{3}{*}{$\$ 4$ million } & & 0.7106 & & -0.1138 & & 0.4820 \\
\hline & & -0.313 & & $(0.0702)$ & & $(0.2299)$ \\
\hline & & -0.7756 & & -1.6212 & & -1.5298 \\
\hline \multirow[t]{3}{*}{ Year of 2008} & 1.0059 & 0.9631 & & & & \\
\hline & -0.5067 & -0.4807 & & & & \\
\hline & 0.0117 & -0.0753 & & & & \\
\hline \multirow[t]{3}{*}{ Year of 2009} & 0.544 & 0.5491 & & & & \\
\hline & -0.2346 & -0.2624 & & & & \\
\hline & -1.4118 & -1.2545 & & & & \\
\hline \multirow[t]{3}{*}{ Year of 2010} & 1.5901 & 1.3827 & & & & \\
\hline & -0.8708 & -0.7898 & & & & \\
\hline & 0.8469 & 0.5673 & & & & \\
\hline \multirow[t]{3}{*}{ Year of 2011} & 0.9566 & 0.7735 & & & & \\
\hline & -0.5309 & -0.4653 & & & & \\
\hline & -0.08 & -0.427 & & & & \\
\hline \multirow[t]{3}{*}{ Year of 2012} & $2.8721 *$ & 2.441 & & & & \\
\hline & -1.8352 & -1.7423 & & & & \\
\hline & 1.6512 & 1.2503 & & & & \\
\hline \multirow[t]{3}{*}{ Constant } & $0.1695^{* * *}$ & $0.2189 * * *$ & $0.1755^{* * *}$ & $0.2111^{* * *}$ & $0.1890 * * *$ & $0.2373 * * *$ \\
\hline & -0.0714 & -0.0973 & $(0.0311)$ & $(0.0501)$ & $(0.0428)$ & $(0.0684)$ \\
\hline & -4.2143 & -3.4177 & 5.6515 & 4.2181 & -7.3488 & -4.9932 \\
\hline Observations & 645 & 645 & 250 & 250 & 250 & 250 \\
\hline F statistic & & & 15.65 & 10.26 & & \\
\hline Prob $>$ F & & & 0 & $4.04 \mathrm{e}-10$ & & \\
\hline Adjusted R-Squared & & & 0.0465 & 0.0360 & & \\
\hline chi squared & 24.61 & 27.87 & & & 9.809 & 13.12 \\
\hline Prob $>$ Fchi 2 & 0.00344 & 0.00339 & & & 0.0438 & 0.0411 \\
\hline Pseudo R-Squared & 0.0505 & 0.0562 & & & 0.0466 & 0.0610 \\
\hline
\end{tabular}

Robust standard errors in parentheses

$* * * \mathrm{p}<0.01, * * \mathrm{p}<0.05, * \mathrm{p}<0.1$ 
TABLE 4-A

ESTIMATES OF DISCRIMINATION AGAINST WHITE MALE NON-DBES VIA DBE GOALS

\begin{tabular}{|c|c|c|c|c|c|c|}
\hline & \multicolumn{6}{|c|}{ Bid Level } \\
\hline & (1) & $(2)$ & (3) & (4) & $(5)$ & (6) \\
\hline & LPM 1 & LPM 2 & LPM 3 & LPM 4 & Logistics 1 & Logistics 2 \\
\hline & $\beta$ & $\beta$ & $\beta$ & $\beta$ & Odds Ratio & Odds Ratio \\
\hline & (r. SE) & (r. SE) & (r. SE) & (r. SE) & (r. SE) & (r. SE) \\
\hline & T-stat & T-stat & T-stat & T-stat & Z-score & Z-score \\
\hline \multirow[t]{3}{*}{ NAICS23 (construction) } & 0.0321 & 0.0557 & -0.0011 & 0.0413 & 1.2688 & 1.5350 \\
\hline & $(0.0513)$ & $(0.0547)$ & $(0.0663)$ & $(0.0684)$ & $(0.4985)$ & $(0.6249)$ \\
\hline & 0.6257 & 1.0167 & -0.0170 & 0.6035 & 0.6060 & 1.0526 \\
\hline \multirow{4}{*}{$\begin{array}{l}\text { Large, Low risk and established } \\
\text { at least } 10 \text { years }\end{array}$} & & & & & & \\
\hline & -0.0371 & -0.0237 & -0.0229 & -0.0051 & 0.7464 & 0.8184 \\
\hline & $(0.0521)$ & $(0.0546)$ & $(0.0522)$ & $(0.0552)$ & $(0.3266)$ & $(0.3685)$ \\
\hline & -0.7123 & -0.4342 & -0.4386 & -0.0922 & -0.6685 & -0.4451 \\
\hline \multirow[t]{3}{*}{ Number of Bids } & -0.0030 & -0.0030 & -0.0033 & -0.0031 & 0.9756 & 0.9755 \\
\hline & $(0.0021)$ & $(0.0021)$ & $(0.0021)$ & $(0.0021)$ & $(0.0178)$ & $(0.0174)$ \\
\hline & -1.4496 & -1.4571 & -1.5936 & -1.5060 & -1.3532 & -1.3916 \\
\hline \multirow[t]{3}{*}{ Contract with DBE goal } & -0.0698 & -0.0528 & -0.0838 & -0.0550 & 0.6179 & 0.7064 \\
\hline & $(0.0790)$ & $(0.0825)$ & $(0.0798)$ & $(0.0807)$ & $(0.3022)$ & $(0.3589)$ \\
\hline & -0.8831 & -0.6398 & -1.0510 & -0.6819 & -0.9844 & -0.6841 \\
\hline \multicolumn{7}{|l|}{ Biding contract amount is over } \\
\hline \multirow[t]{3}{*}{$\$ 4$ million } & & -0.0737 & & -0.1321 & & 0.5233 \\
\hline & & $(0.0584)$ & & $(0.0906)$ & & $(0.2775)$ \\
\hline & & -1.2615 & & -1.4576 & & -1.2213 \\
\hline \multirow[t]{3}{*}{ Year of 2008} & & & -0.0582 & -0.0818 & & \\
\hline & & & $(0.1163)$ & $(0.1120)$ & & \\
\hline & & & -0.5004 & -0.7306 & & \\
\hline \multirow[t]{3}{*}{ Year of 2009} & & & -0.1231 & $-0.1883^{*}$ & & \\
\hline & & & $(0.0914)$ & $(0.1083)$ & & \\
\hline & & & -1.3468 & -1.7380 & & \\
\hline \multirow[t]{3}{*}{ Year of 2010} & & & -0.1519 & -0.1798 & & \\
\hline & & & $(0.1280)$ & $(0.1265)$ & & \\
\hline & & & -1.1870 & -1.4212 & & \\
\hline \multirow[t]{3}{*}{ Year of 2011} & & & -0.0934 & -0.1860 & & \\
\hline & & & $(0.1245)$ & $(0.1581)$ & & \\
\hline & & & -0.7498 & -1.1764 & & \\
\hline \multirow[t]{3}{*}{ Year of 2012} & & & 0.1025 & -0.0089 & & \\
\hline & & & $(0.1828)$ & $(0.2012)$ & & \\
\hline & & & 0.5609 & -0.0442 & & \\
\hline \multirow[t]{3}{*}{ Constant } & $0.2531 * * *$ & $0.2448 * * *$ & $0.3690 * * *$ & $0.4089^{* * *}$ & $0.3661 * *$ & $0.3425 * *$ \\
\hline & $(0.0816)$ & $(0.0826)$ & $(0.1223)$ & $(0.1261)$ & $(0.1839)$ & $(0.1755)$ \\
\hline & 3.1042 & 2.9640 & 3.0168 & 3.2416 & -2.0006 & -2.0908 \\
\hline Observations & 201 & 201 & 201 & 201 & 201 & 201 \\
\hline F statistic & 1.040 & 1.237 & 0.743 & 0.880 & & \\
\hline Prob $>F$ & 0.388 & 0.293 & 0.669 & 0.553 & & \\
\hline Adjusted R-Squared & -0.00288 & -0.00114 & -0.00290 & 0.00752 & & \\
\hline chi squared & & & & & 4.360 & 6.110 \\
\hline Prob $>$ Fchi 2 & & & & & 0.359 & 0.296 \\
\hline Pseudo R-Squared & & & & & 0.0199 & 0.0287 \\
\hline
\end{tabular}

Robust standard errors in parentheses

$* * * \mathrm{p}<0.01, * * \mathrm{p}<0.05, * \mathrm{p}<0.1$ 
TABLE 4-B

ESTIMATES OF DISCRIMINATION AGAINST WHITE MALE NON-DBES VIA DBE GOALS

\begin{tabular}{|c|c|c|c|c|c|c|}
\hline & \multicolumn{2}{|c|}{ Bid Level } & \multicolumn{4}{|c|}{ Bidder Level } \\
\hline & $(1)$ & $(2)$ & (3) & (4) & (5) & $(6)$ \\
\hline & Logistics 3 & Logistics 4 & LPM 5 & LPM 6 & Logistics 5 & Logistics 6 \\
\hline & $\begin{array}{l}\text { Odds Ratio } \\
\text { (r. SE) }\end{array}$ & $\begin{array}{l}\text { Odds Ratio } \\
\text { (r. SE) }\end{array}$ & $\begin{array}{c}\beta \\
\text { (r. SE) }\end{array}$ & $\begin{array}{c}\beta \\
\text { (r. SE) }\end{array}$ & $\begin{array}{l}\text { Odds Ratio } \\
\text { (r. SE) }\end{array}$ & $\begin{array}{l}\text { Odds Ratio } \\
\text { (r. SE) }\end{array}$ \\
\hline \multirow[t]{3}{*}{ NAICS23 (construction) } & 0.9545 & 1.3070 & 0.0134 & 0.0693 & 1.0552 & 1.4145 \\
\hline & $(0.5068)$ & $(0.6666)$ & $(0.1168)$ & $(0.1221)$ & $(0.6166)$ & $(0.8731)$ \\
\hline & -0.0878 & 0.5249 & 0.1145 & 0.5675 & 0.0920 & 0.5619 \\
\hline \multirow{3}{*}{$\begin{array}{l}\text { Large, Low risk and established } \\
\text { at least } 10 \text { years }\end{array}$} & 0.8135 & 0.9356 & 0.1716 & 0.1865 & 2.2277 & 2.5258 \\
\hline & $(0.3665)$ & $(0.4337)$ & $(0.1418)$ & $(0.1412)$ & $(1.4092)$ & $(1.6620)$ \\
\hline & -0.4582 & -0.1437 & 1.2100 & 1.3215 & 1.2663 & 1.4082 \\
\hline \multirow[t]{3}{*}{ Number of Bids } & 0.9719 & 0.9712 & 0.0090 & 0.0089 & 1.0426 & 1.0452 \\
\hline & $(0.0183)$ & $(0.0185)$ & $(0.0073)$ & $(0.0069)$ & $(0.0340)$ & $(0.0319)$ \\
\hline & -1.5143 & -1.5334 & 1.2283 & 1.2838 & 1.2798 & 1.4471 \\
\hline \multirow[t]{3}{*}{ Contract with DBE goal } & 0.5458 & 0.6938 & $-0.2804^{*}$ & -0.2404 & $0.2829 *$ & 0.3381 \\
\hline & $(0.2801)$ & $(0.3648)$ & $(0.1531)$ & $(0.1621)$ & $(0.1910)$ & $(0.2422)$ \\
\hline & -1.1800 & -0.6953 & -1.8316 & -1.4829 & -1.8703 & -1.5135 \\
\hline \multirow{3}{*}{$\begin{array}{l}\text { Biding contract amount is over } \\
\$ 4 \text { million }\end{array}$} & & 0.2849 & & -0.1838 & & 0.3353 \\
\hline & & $(0.2496)$ & & $(0.1222)$ & & $(0.2501)$ \\
\hline & & -1.4332 & & -1.5040 & & -1.4651 \\
\hline \multirow[t]{3}{*}{ Year of 2008} & 0.6593 & 0.5117 & & & & \\
\hline & $(0.4690)$ & $(0.3541)$ & & & & \\
\hline & -0.5856 & -0.9682 & & & & \\
\hline \multirow[t]{3}{*}{ Year of 2009} & 0.3924 & $0.2062 *$ & & & & \\
\hline & $(0.2368)$ & $(0.1768)$ & & & & \\
\hline & -1.5501 & -1.8416 & & & & \\
\hline \multirow[t]{3}{*}{ Year of 2010} & 0.3166 & 0.2145 & & & & \\
\hline & $(0.2948)$ & $(0.2186)$ & & & & \\
\hline & -1.2353 & -1.5101 & & & & \\
\hline \multirow[t]{3}{*}{ Year of 2011} & 0.5113 & 0.2274 & & - & & \\
\hline & $(0.4306)$ & $(0.2527)$ & & & & \\
\hline & -0.7965 & -1.3330 & & - & & \\
\hline \multirow[t]{3}{*}{ Year of 2012} & 1.6546 & 0.6353 & & & & \\
\hline & $(1.4890)$ & $(0.6574)$ & & & & \\
\hline & 0.5596 & -0.4384 & & & & \\
\hline \multirow[t]{3}{*}{ Constant } & 0.8862 & 1.3831 & $0.4321 * * *$ & $0.4163 * *$ & 0.7250 & 0.6542 \\
\hline & $(0.6775)$ & $(1.2332)$ & $(0.1576)$ & $(0.1607)$ & $(0.4679)$ & $(0.4336)$ \\
\hline & -0.1580 & 0.3637 & 2.7419 & 2.5903 & -0.4982 & -0.6402 \\
\hline Observations & 201 & 201 & 67 & 67 & 67 & 67 \\
\hline F statistic & & & 1.865 & 2.375 & & \\
\hline Prob $>$ F & & & 0.128 & 0.0492 & & \\
\hline Adjusted R-Squared & & & 0.0416 & 0.0512 & & \\
\hline chi squared & 7.148 & 8.333 & & & 6.372 & 8.052 \\
\hline Prob $>$ Fchi 2 & 0.622 & 0.596 & & & 0.173 & 0.153 \\
\hline Pseudo R-Squared & 0.0473 & 0.0687 & & & 0.0778 & 0.101 \\
\hline
\end{tabular}

Robust standard errors in parentheses

$* * * \mathrm{p}<0.01, * * \mathrm{p}<0.05, * \mathrm{p}<0.1$ 